\title{
Does Hued Lubricant Jelly Prevent Stone Migration/Retropulsion During Semi-rigid Ureterorenoscopy and Pneumatic Lithotripsy?
}

\author{
Renkli Lubrikant Jel Yarı Rijit Üreterorenoskopi ve Pnömatik Litotripsi Sırasında Taş \\ Migrasyonunu/Retropülsiyonunu Önler mi?
}

\author{
(D) Siddalingeshwar Neeli, (D) Amey Patil, (D) Srikanth Pentyala \\ Jawaharlal Nehru Medical College, Department of Urology, Belagavi, India
}

\section{What's known on the subject? and What does the study add?}

Retropulsion of calculus during rigid ureteroscopy is a known outcome and various mechanisms have been tried to prevent it including jelly. However, because the jelly is a colorless fluid, it is not easy to visualise it after instillation. We have used jelly mixed with methylene blue so as to make both the stone and jelly to be visualised easily simultaneously.

\begin{abstract}
Objective: The aim of this study is to study the efficacy of hued lubricating jelly instillation proximal to the upper ureteral stone during intracorporial pneumatic lithotripsy using semi-rigid ureteroscope for the prevention of migration of the stone.

Materials and Methods: We enrolled 60 subjects with ureteral stone in this prospective, controlled clinical trial. Alternate patients were assigned to the hued lubricating jelly instillation group $A(n=30)$ and control group $B(n=30)$. Ureteroscopy was performed according the standard protocol, using 7.5 F semi-rigid ureteroscope and stone fragmentation by pneumatic lithotripter. In the group A patients, a $5 \mathrm{Fr}$ catheter was inserted into the ureter under fluoroscopy and 3-5 mL of hued lubricant jelly was dispensed above the stone. Retropulsion and the presence of residual fragments were evaluated with computed tomography of kidneys, ureters and bladder, X-ray and ultrasonography at 24 hours and at two weeks. The migrated stones were treated with shock wave lithotripsy. Any adverse event was reported and graded as per the modified Clavien classification system.

Results: The two groups had comparable demographic and stone characteristics. There was a statistically significant difference in retropulsion rate between the lubricating jelly instillation group and control group (6.67\% vs $26.67 \%, p=0.04)$. No statistically significant complications were noted amongst the two groups. All patients were stone-free at 2-week follow-up.

Conclusion: Instillation of hued lubricating jelly proximal to ureteral calculi during pneumatic lithotripsy is an effective method of preventing retrograde stone migration.
\end{abstract}

Keywords: Ureteroscopy, Lithotripsy, Retropulsion, Migration, Lubricating jelly instillation

\section{Öz}

Amaç: Bu çalışmada intrakorporial pnömotik litotripsi sırasında taş migrasyonunun önlenmesi için semi-rijit üreteroskop kullanılarak, proksimal üst üreter taşına renkli lubrikant jel instilasyon etkinliğinin incelenmesi amaçlanmıştır.

Gereç ve Yöntem: Bu prospektif, kontrollü çalışmaya üreter taşı olan 60 kişiyi dahil ettik. Alternatif hastalar, renkli lubrikant jel instilasyon grubu A $(n=30)$ ve kontrol grubu B'ye $(n=30)$ ayrıldı. Üreteroskopi, standart protokole göre 7,5 F semi-rijit üreteroskop ve pnömatik litotriptör ile taş parçalama yöntemi kullanılarak yapıldı. A grubundaki hastalara, üreter içerisine floroskopi altında $5 \mathrm{Fr}$ kateter yerleştirildi ve 3-5 mL renkli lubrikant jel taş üzerine dağıtıldı. Retropülsiyon ve kalan parçaların varlığı 24 saatte ve iki haftada böbrekler, üreterler ve mesane düz bilgisayarlı tomografisi, X-ray ve ultrasonografi ile değerlendirildi. Migrate olan taşlar şok dalga litotripsi ile tedavi edildi. Her bir advers olay modifiye Clavien sınıflama sistemine göre rapor edildi ve derecelendirildi.

Bulgular: İki grup benzer demografik ve taş özelliklerine sahipti. Lubrikant jel instilasyon grubu ve kontrol grubu arasında retropülsiyon oranları (\%6,67'ye karşı \%26,67, p=0,04) açısından istatistiksel olarak anlamlı farklılık vardı. İki grup arasında istatistiksel olarak anlamlı bir komplikasyon görülmedi. Bütün hastaların iki haftalık takip sonrasında taşı yoktu.

Correspondence: Siddalingeshwar Neeli MD, Jawaharlal Nehru Medical College, Department of Urology, Belagavi, India Phone: +91-9880977367 E-mail: sineeli@gmail.com ORCID-ID: orcid.org/0000-0001-6565-1443

Received: $13.05 .2018 \quad$ Accepted: 02.09.2018

Cite this article as: Neeli S, Patil A, Pentyala S. Does Hued Lubricant Jelly Prevent Stone Migration/Retropulsion During Semi-rigid Ureterorenoscopy and Pneumatic Lithotripsy? J Urol Surg 2019;6(1):11-15.

๑Copyright 2019 by the Association of Urological Surgery / Journal of Urological Surgery published by Galenos Publishing House. 
Sonuç: Pnömatik litotripsi esnasında proksimal üretral taşa renkli lubrikant jel instilasyonu yapılması, retrograd taş migrasyonunu önlemede etkili bir yöntemdir.

Anahtar Kelimeler: Üreteroskopi, Litotripsi, Retropülsiyon, Migrasyon, Lubrikant jel instilasyonu

\section{Introduction}

The rising incidence of ureteric stones has made the procedure of ureterorenoscopy (URS) common in recent times $(1,2)$. The success of URS depends upon various factors such as stone size, location, degree of proximal hydronephrosis, and the energy source used to break the stone (pneumatic lithoclast/laser) (3). One of the important variable remains migration or retropulsion of stone during the procedure (4). Various studies have reported that $28 \%$ to $48 \%(5,6,7)$ of proximal ureteric stones and $3 \%$ to $15 \%(8,9)$ of distal ureteric stones undergo migration during URS. The migration of the calculus will warrant an additional procedure in the form of extra-corporeal shock wave lithotripsy (SWL) or flexible URS and laser lithotripsy. Stone migration results in decreased stone clearance rates, increased operative time and additional costs and morbidity of second procedure $(10,11)$. In the era of rising health-care expenses, any advancement to make the procedure cheaper and effective is welcome. Various novel devices, such as stone cones, gels, trapping devices etc., have been described to prevent stone migration $(3,4,5,6,7,8,9,10,11,12)$ with differing efficacy rates. However, the costs and availability of these is a major issue $(3,4,5,6,7,8,9,10,11,12)$.

We studied the effectiveness of a hued lubricant gel (lubricating jelly mixed with methylene blue), an easily available and cheap gel, in preventing the retropulsion of upper ureteric (at or above the level of $L 5$ lumbar vertebral transverse process) stone during URS while using pneumatic lithoclast.

\section{Materials and Methods}

From June 2016 to December 2017, after institutional review board approval (approval number: MDC/DOME/495, JNMC Institutional Ethics Committee on Human Subjects Research) and obtaining written informed consent from the participants, 60 patients with upper ureteral stones $(7-15 \mathrm{~mm})$ requiring ureteroscopy were enrolled in this study.

All patients were evaluated by history taking, physical examination, laboratory investigations, including urinalysis, full blood count, and renal function test. Preoperative radiographic imaging studies, including X-ray of kidneys, ureters and bladder (KUB), ultrasound, and computed tomography (CT) scan were performed and stone size, location, opacity, and degree of obstruction were documented.
All patients diagnosed to have calculus present in the upper ureter (defined as calculus present at or above the level of $L 5$ vertebral transverse process) were eligible for the study.

Exclusion criteria included patients below 18 years, those having active urinary infection, obstructive uropathy, underlying chronic kidney disease, and impacted calculus.

Patients were divided into two treatments groups: group A of 30 patients who received hued jelly instillation before intracorporeal lithotripsy using pneumatic lithoclast and group $B$ of 30 patients who were treated with conventional method without jelly. Alternate patients were allocated to group A and group B. The operation was performed under general anesthesia and all patients received a single broad-spectrum antibiotic parenterally at the time of induction.

Ureteroscopy and stone fragmentation were performed using a $7.5 \mathrm{Fr}$ Olympus semi-rigid ureteroscope and Swiss LithoClast. Saline was used as the irrigation fluid. A colorless lubricant jelly was hued by mixing with methylene blue. $8 \mathrm{~mL}$ of lubricant jelly (K-Y Jelly, Johnson\&Johnson, USA) was mixed with $2 \mathrm{~mL}$ of methylene blue in a sterile container and then loaded in a 10 $\mathrm{mL}$ syringe for instillation. Cystoscopy and retrograde urography were routinely performed and a guide-wire was passed to the renal pelvis. Prior to stone fragmentation, in the group A patients, $5 \mathrm{Fr}$ catheter was inserted into the ureter over a guidewire under fluoroscopy and 3-5 $\mathrm{mL}$ of hued jelly was dispensed above the stone and the catheter was removed (Figure 1). In the group B patients, no anti-retropulsion device was used. The Swiss LithoClast was used for stone fragmentation with

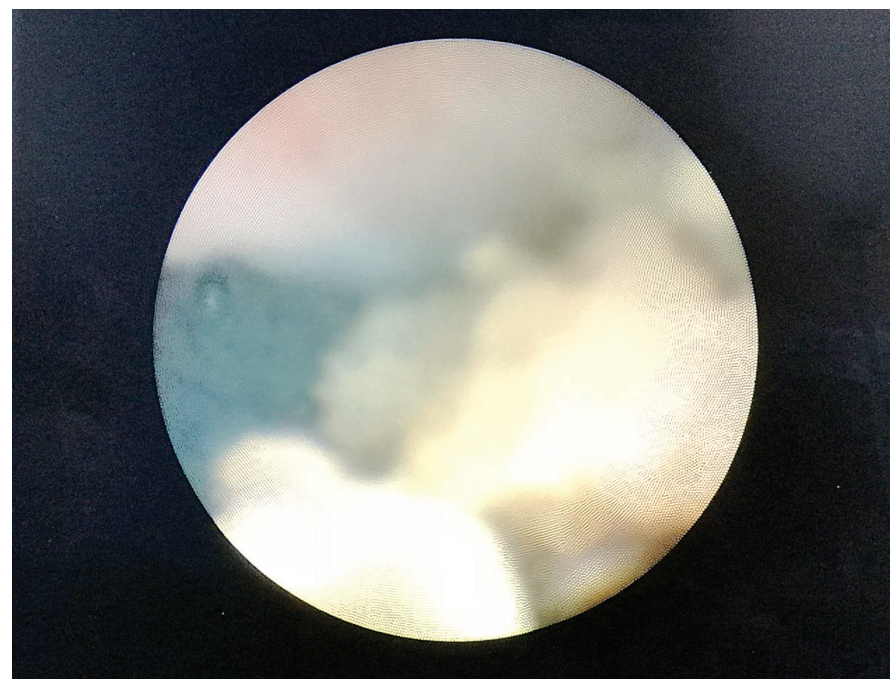

Figure 1. Endoscopic view of stone after instillation of hued lubrication jelly 
$300 \mathrm{kPa}$ pressure and a $3.5 \mathrm{Fr}$ rod. The stones were fragmented to approximately 1-3 $\mathrm{mm}$ particles and were allowed to pass spontaneously. The remaining jelly was washed out with saline at the end of the procedure. In all patients, a 5 Fr double J (DJ) stent was inserted and left in place for 2 weeks. A Foley catheter was inserted in all of our patients and was removed on the next day. Operative time was calculated from the time of cystoscope insertion to the completion of the procedure.

CT scan of the KUB was performed after 24 hours to exclude stone migration and confirm stone clearance. Stone migration was defined as stone retropulsion into the pelvicalyceal system. Patients who had stone migration were subjected to SWL treatment. The patients were discharged on the first postoperative day or 24 hours after SWL treatment and were advised to take oral antibiotic for 5 days. All patients were followed up for 2 weeks and underwent DJ stent removal after radiological confirmation of stone clearance with KUB X-ray, ultrasound and CT. For all the subjects, any adverse events were assessed and reported at 24 hours postoperatively and at the 2-week follow-up visit.

A sample size of 54 patients was calculated using comparing two proportion formulas. It was estimated to yield $80 \%$ power (type 2 or beta error of $0.20 \%$ ) to detect a difference of $20 \%$ or more between the two groups ( $40 \%$ migration rate in no jelly group and 20\% migration in the hued jelly group), allowing 5\% of type 1 error. Totally, 60 patients were enrolled in the study.

\section{Statistical Analysis}

All data were analyzed using SPSS 20 (SPSS, Chicago, IL, USA) software. Continuous variables with normal distribution were presented as mean \pm standard deviation and were compared by the independent samples t-test and paired t-test. Nominal variables were taken as counts (or frequencies) and were compared by a chi-square test. The stone migration rates and the stone-free rates in the two groups were compared by the cross tabulation analysis. All statistical tests were reported based on two tailed probability. A p value of less than 0.05 was considered statistically significant.

\section{Results}

A total of 30 patients underwent URS with deployment of hued lubricating jelly in group A and 30 without in group B. The patient profiles were similar in both groups regarding age, mean largest dimension of the stone (Table 1). The mean time to deploy hued jelly was 146.5 seconds (standard deviation: 34.57). The mean lithotripsy time was 13.7 minutes in group $A$ and 13 minutes in group B. All the procedures were completed within one hour. Stone retropulsion occurred in 2 cases (6.67\%) in group A and in $8(26.67 \%)$ patients in group B $(p=0.04)$ (Table 2). All patients having retropulsion of the calculus were successfully treated with SWL. Patients with retropulsion had to stay one day more than planned treatment. Two patients each from the gel arm and the control group had fever in the postoperative period needing paracetamol, while 1 patient in group B had hematuria which resolved spontaneously. However, no serious complications such as ureteral perforation, avulsion or ureteral stricture occurred in either group. All patients were stone-free at the time of DJ stent removal.

\section{Discussion}

Stone migration during ureteroscopy remains a concern and has the potential to increase operative time, need for additional procedure and the health-care cost of the treatment $(3,4,12)$. Moreover, residual stone fragments can act as a nidus for recurrent stone formation, recurrent urinary tract infection, and renal colic (13). A number of novel accessory instruments, devices, and strategies have been introduced into the field of ureteroscopic lithotripsy to address the problem of proximal stone migration. The currently available anti-retropulsion devices are either: 1) mechanical, wire based; 2) mechanical, balloon based; or 3$)$ gel based $(3,4,12)$.

While the mechanical devices like stone cone, NTrap and balloons achieve some level of effectiveness in preventing stone migration, they use mechanical elements that can potentially cause trauma to the ureter or interfere with the safe working of the energy source $(12,14)$. They require that a wire remain in the ureter, encumbering the operative field and potentially

Table 1. Patient demographics and stone size

\begin{tabular}{llll}
\hline & $\begin{array}{l}\text { Group A } \\
(\mathbf{n = 3 0 )}\end{array}$ & $\begin{array}{l}\text { Group B } \\
(\mathbf{n = 3 0 )}\end{array}$ & p values \\
\hline Gender & & & \\
\hline Male & 19 & 14 & 0.15 \\
Female & 11 & 16 & \\
\hline Mean age (years) & $41+/-16$ & $40+/-15$ & 0.88 \\
\hline Stone size $(\mathrm{mm})$ & $9.39+/-2.39$ & $9.17+/-1.9$ & 0.72
\end{tabular}

Table 2. Intraoperative and postoperative outcomes

\begin{tabular}{llll}
\hline & $\begin{array}{l}\text { Group A } \\
(\mathbf{n}=\mathbf{3 0})\end{array}$ & $\begin{array}{l}\text { Group B } \\
(\mathbf{n}=\mathbf{3 0})\end{array}$ & p values \\
\hline $\begin{array}{l}\text { Jelly deployment time } \\
\text { (seconds) }\end{array}$ & $\begin{array}{l}146.5 \\
(\mathrm{SD}: 34.57)\end{array}$ & - & - \\
\hline $\begin{array}{l}\text { Total procedure time } \\
\text { (minutes) }\end{array}$ & $33.83+/-6.62$ & $30.00+/-6.47$ & 0.027 \\
\hline Stone migration & $2(6.67 \%)$ & $8(26.67 \%)$ & 0.04 \\
\hline Adverse events & $2(6.67 \%)$ & $3(10 \%)$ & 0.50 \\
\hline SD: Standard deviation & & & \\
\hline
\end{tabular}


inhibiting ureteroscope maneuverability, and may allow smaller fragments to migrate (12).

Similar to mechanical devices, different gel-based barriers have been tried to prevent stone migration. Ali et al. (15) instilled lubricant gel proximal to the ureteric calculus before applying kinetic energy and were successful in adequately fragmenting and preventing stone migration in 7 patients they treated. Mohseni et al. (16) found lubricating jelly to be an effective method of preventing retrograde stone displacement when instilled proximal to the ureteral stone during lithotripsy in 16 patients. However, they found no significant difference in the stone-free rates when compared to control group.

Zehri et al. (17) used 2\% lidocaine gel for instillation in 25 patients and reported a statistically significantly lower rate of stone migration in those patients. They also noted that the use of lidocaine jelly had the potential to impair visibility during ureteroscopy (17). In a similar study using lidocaine gel, Saad et al. (18) noticed a decreased migration rate and also a significantly higher stone-free rate in patients of the lidocaine group at 1-month follow-up.

A randomized trial using BackStopTM, a reverse-thermosensitive gel, conducted by Rane et al. (12) found stone retropulsion in $8.8 \%$ of 34 patients who were randomized to BackStopTM group and in $52.9 \%$ of 34 controls ( $p=0.0002$ ). The use of BackStopTM was not associated with any short-term adverse events while four cases in the control group had complications including one incident of ureteral stricture (12).

In the present study, we deployed hued jelly proximal to the stone prior to fragmentation. The advantage of coloring the jelly was that the presence of the jelly and the stone fragments being stopped from getting migrated by the colored gel were easily visualized during ureteroscopy. In our study, use of hued lubricant jelly resulted in a statistically significantly lower stone migration rate of $6.6 \%$ compared to $26.6 \%$ in controls $(p=0.04)$. The mean operation time in the jelly group was 33.8 minutes while it was 30 minutes in controls $(p=0.027)$. Though minor adverse events were noted in both groups, they were not statistically significant. However, all the subjects in the study were free of stones at 2-week follow-up and underwent DJ stent removal. In the present study, we had to increase the intensity of the light during the procedure as some of it was getting absorbed by the colored jelly, however, the stone and the gel were visualized distinctly in all the cases. Also, we had to be cautious with irrigation during the procedure as to not dislodge the jelly.

\section{Study Limitations}

Our study was a single center trial. Multicenter trials are needed to assess the ease of preparing the colored jelly and its deployment proximal to the stone. Also, we have not addressed the operative time and procedure-related cost in the present study.

\section{Conclusion}

During ureteroscopy using a pneumatic lithotripsy device to treat ureteric stones, instillation of hued lubrication jelly proximal to the stone prior to lithotripsy is effective in preventing stone retropulsion. However, its effect on improving the stone-free rate was not significant in our study.

\section{Ethics}

Ethics Committee Approval: The approval was taken from JNMC Institutional Ethics Committee on Human Subjects Research (number: MDC/DOME/495, date: 14.03.2016).

Informed Consent: It was taken in the vernacular language spoken by the patient (Kannada, Marathi and Hindi).

Peer-review: Externally peer-reviewed.

\section{Authorship Contributions}

Surgical and Medical Practices: S.N., A.P., S.P., Concept: S.N., Design: S.N., Data Collection or Processing: S.N., A.P., S.P., Analysis or Interpretation: S.N., Literature Search: S.N., A.P., Writing: S.N., A.P.

Conflict of Interest: No conflict of interest was declared by the authors.

Financial Disclosure: The authors declared that this study received no financial support.

\section{References}

1. Romero $\mathrm{V}$, Akpinar $\mathrm{H}$, Assimos DG. Kidney stones: a global picture of prevalence, incidence, and associated risk factors. Rev Urol 2010;12:86-96.

2. Turney BW, Reynard JM, Noble JG, Keoghane SR. Trends in urological stone disease. BJU Int 2012;109:1082-1087.

3. Ahmed M, Pedro RN, Kieley S, Akornor JW, Durfee WK, Monga M. Systematic evaluation of ureteral occlusion devices: insertion, deployment, stone migration, and extraction. Urology 2009;73:976-980.

4. Elashry OM, Tawfik AM. Preventing stone retropulsion during intracorporeal lithotripsy. Nat Rev Urol 2012;12:691-698.

5. Chow GK, Patterson DE, Blute ML Segura JW. Ureteroscopy: effect of technology and technique on clinical practice. J Urol 2003;170:99-102.

6. Knispel HH, Klän R, Heicappell R, Miller K. Pneumatic lithotripsy applied through deflected working channel of miniureteroscope: results in 143 patients. J Endourol 1998;12:513-515.

7. Robert M, Bennani A, Guiter J, Avérous M, Grasset D. Treatment of 150 ureteric calculi with the Lithoclast. Eur Urol 1994;26:212-215.

8. Hendrikx AJ, Strijbos WE, de Knijff DW, Kums JJ, Doesburg WH, Lemmens WA. Treatment for extended-mid and distal ureteral stones: SWL or ureteroscopy? Results of a multicenter study. J Endourol 1999;13:727-733. 
9. Pardalidis NP, Kosmaoglou EV, Kapotis CG. Endoscopy vs. extracorporeal shockwave lithotripsy in the treatment of distal ureteral stones: ten years' experience. J Endourol 1999;13:161-164.

10. Lee H, Ryan RT, Teichman JM, Kim J, Choi B, Arakeri NV, Welch AJ. Stone retropulsion during holmium:YAG lithotripsy. J Urol 2003;169:881-885.

11. Dretler SP. The stone cone: a new generation of basketry. J Urol 2001;165:1593-1596.

12. Rane A, Bradoo A, Rao P, Shivde $S$, Elhilali M, Anidjar M, Pace $K$, D'A Honey JR. The use of a novel reverse thermosensitive polymer to prevent ureteral stone retropulsion during intracorporeal lithotripsy: A randomized controlled trial. J Urol 2010;183:1417-1423.

13. Delvecchio FC, Preminger GM. Management of residual stones. Urol Clin North Am 2000;27:347-354.

14. Dretler SP. Preventing stone migration during ureteroscopy: the Stone Cone "rules". Contemp Urol 2006;18:57.
15. Ali AA, Ali ZA, Halstead JC, Yousaf MW, Ewah P. A novel method to prevent retrograde displacement of ureteric calculi during intracorporeal lithotripsy. BJU Int 2004;94:441-442.

16. Mohseni $M G$, Arasteh $S$, Alizadeh F. Preventing retrograde stone displacement during pneumatic lithotripsy for ureteral calculi using lidocaine jelly. Urology 2006;68:505-507.

17. Zehri AA, Ather MH, Siddiqui KM, Sulaiman MN. A randomized clinical trial of lidocaine jelly for prevention of inadvertent retrograde stone migration during pneumatic lithotripsy of ureteral stone. J Urol 2008;180:966-968.

18. Al-Sammarraie SH, Al-Dabbagh AA, Ahmed SB. The Efficacy of Using Lidocaine Jelly $2 \%$ for Prevention of Inadvertent Retrograde Stone Displacement during Pneumatic Lithotripsy of Upper Ureteral Stone. International Journal of Science and Research (IJSR) 2016;5:2166-2169. 